\title{
Water history in the time of COVID-19: cancelled conversations
}

\author{
Seohyun Park ${ }^{1}$ Scot McFarlane ${ }^{2} \cdot$ Adam Sundberg $^{3} \cdot$ Tino Mager $^{4} \cdot$ Henk van Schaik ${ }^{5}$. \\ Arie Den Boer ${ }^{6}$. Priyanka Sheth ${ }^{7}$. Aashini Sheth ${ }^{8}$
}

(c) Springer Nature B.V. 2021

In the months following the emergence of COVID-19 as a global force, many academic conferences were cancelled. Such meetings are the life-force of international scholarly communities, and are places where ideas are shared, projects are introduced, and potential collaborators meet. This year, many important conversations were interrupted. And so we reached out to scholars who had planned on presenting on water history and invited them to submit papers as short pieces in order to give them a chance to introduce themselves and their projects to the broader community. We treated these differently from regular submissions, accepting them as pre-peer reviewed in as much as they had been selected by conferences. These are, notably, works in progress rather than final pieces, and the authors of these short pieces welcome your feedback, support, and suggestions, much as they would do so at conferences. In the interest of beginning to find new ways of using journal

Seohyun Park

seohyun@vt.edu

Scot McFarlane

wsm2116@columbia.edu

Adam Sundberg

ads135@gmail.com

Tino Mager

tino.mager@rug.nl

Arie Den Boer

arie.den.boer@planet.nl

Priyanka Sheth

priyanka.sheth13@gmail.com

1 Virginia Polytechnic Institute and State University, Blacksburg, USA

2 Columbia University, New York, USA

3 Creighton University, Omaha, USA

4 University of Groningen, Groningen, The Netherlands

5 ICOMOS, Amsterdam, The Netherlands

6 Erasmus University Amsterdam, Amsterdam, The Netherlands

7 Beyer Blinder Belle Architects and Planners New York, New York, USA

8 CEPT University, Ahmedabad, India 
platforms creatively to enhance scholarly conversation rather than gate-keep, we are proud to share with you the following short pieces.

\section{Turning a river into a national resource: hydrological engineering in Cold War Korea}

\section{Seohyun Park}

This essay introduces my dissertation project that examines hydrological engineers who envisioned, designed, and implemented the Han River Basin development in Cold War Korea. This essay was supposed to be presented at the 2020 American Society for Environmental History annual meeting in Ottawa, Canada. I aimed to use this presentation as an opportunity to make my scholarship engage with environmental history.

In April 1965, M. E. Von Seggern, J. T. Callahan, and William F. MacMillan-three American engineers from the U.S. Bureau of Reclamation (USBR) and the U.S. Geological Survey (USGS) - arrived in South Korea. They visited the small country to investigate the economic potential of the Han River, the so-called "lifeline of the nation." These engineers had expertise in hydrology, the study of the water cycle and its relationship with the environment. After two months of field study, they concluded that the Han River basin had "a very large and valuable water resource" (Seggern et al. 1965, p. 1). This preliminary survey inspired Park Chung-hee's military regime, which had come to power through a military coup in 1961, to initiate a nationwide river basin survey project. The three American engineers' trip across the Pacific was a starting point of national river engineering, which has since dramatically transformed South Korea's landscape.

My research examines the experts who envisioned, designed, and implemented river basin development in South Korea in order to show how river engineering was rationalized. Historians have explored the various politics behind river development practices across the globe from a local to an international scale (Frioux 2014; Mauch \& Zeller 2008; Schönach 2017). Yet, they have paid less attention to the hydrological engineers who provided the rationale for river engineering by measuring the physical and ecological characteristics of river water, gathering precipitation, water level, and water flow data produced in the past, estimating the movement of river water, and designing a master plan for river basin development. Without an adequate analysis of these experts, it is difficult to question the political, cultural, and ethical choices embedded in the fundamental grounds for river engineering.

In the Korean context, professional hydrological engineering emerged during the 1960s based on the colonial experiences of river management and Cold War foreign aid from the U.S. While American capital and technical know-how promoted the emergence of hydrological engineering in Korea, colonial infrastructure-including water gauging stations, hydrological knowledge, data, and institutions_-generated by Japanese colonizers provided valuable sources for hydrological engineers to rely on. The newly emerged Korean hydrological engineers' goals mostly aligned with those of the political elites, but they also attempted to construct distinctive identities as contributors to the national vision of rapid economic growth. My dissertation sheds light on how hydrological engineers planned the national river basin development with an invention of a particular perspective on the natural and social world, while redistributing resources in favor of the nation's vision of economic growth. 
Drawing on archival sources from Korea and the United States, I argue that hydrological engineers rationalized high-cost and large dam construction projects by converting the natural environment into national resources. Hydrological engineering evolved in South Korea from dynamic tensions between the authoritarian regime's political aspirations, the global Cold War order, and colonial legacies. From the late 1950s, the U.S. government attempted several projects to transfer a river basin development model to help South Korea reconstruct the postwar nation and defend against Communist threats with economic abundance (UNC Economic Coordinator 1959; Combined Economic Board 1958; Smith Hinchman $\&$ Grylls Associates 1960). These early efforts provided the basis for the detailed survey project on the Han River, also known as the Han River Basin Joint Survey (1966-1971).

However, hydrology is never universal; it requires specific data and knowledge about the local environment. Throughout the survey project, American engineers introduced advanced devices for gathering hydrological data and trained Korean engineers on the procedures and methods for river basin development, but American and Korean engineers had difficulty applying these techniques to the local environment (Kim 1969). In order to understand the hydrological characteristics of the Han River and to plan river basin development, the survey team had to rely on knowledge and data gathered during the Japanese colonial period (1910-1945) by Japanese officials attempting to control the colonized riverine environment systematically. These past hydrological data of water level, precipitation, and streamflow helped the survey team estimate the amount of annual river water flow.

Based on the Han River basin survey, hydrological engineers reduced a complex river system with many users to being solely a water supplier for the nation. According to their survey, more than half of the annual runoff had been wasted, meaning that the water flowed into the sea without nourishing farmland, feeding municipalities, and generating electricity. Hydrological engineers asserted that securing wasted river water into artificial reservoirs and maximizing the use of water would lead to "the expansion of industry, an increase in the gross national product, a higher level of employment, and an improvement in the general standard of living" (Seggern et al. 1965, p. 1).

This claim was sold to Park Chung-hee's authoritarian regime, which aspired to reconstruct South Korea by showing its superiority over North Korea through its economic performance. The Park regime assisted in the establishment of the Korea Water Resources Development Corporation (KWRDC) in 1967 to endow a responsibility to construct and manage multi-purpose dams, canals, and reservoirs (KTV 1967). The KWRDC became an incubator for hydrological engineers and imbued South Korean society with the idea that multi-purpose dam construction would be a magic bullet for national progress. Ahn Kyung-mo, the CEO of the KWRDC from 1967 to 1983, proclaimed that the KWRDC "carved the mountains, filled the sea, impounded water, and constructed dams" like "a piece of artwork" to achieve national economic growth (Ahn 1991). 


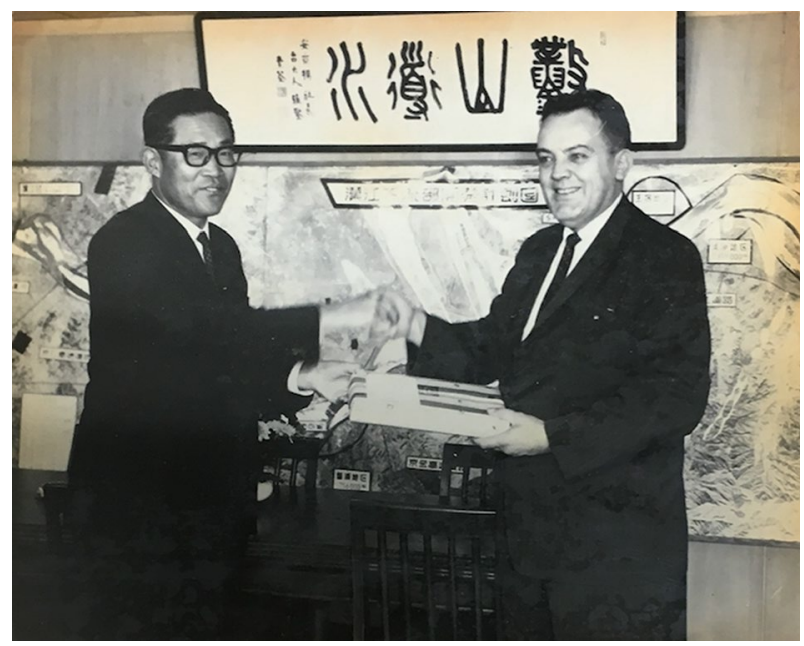

Fig. 1. Ahn Kyung-mo and Gilbert G. Stamm from the USBR with the Han River basin map behind them. Source (Korea Water Resources Development Corporation, 1968)

The hydrological study marked river water as an under-developed resource for the nation. Hydrological engineers legitimized dam construction with the assertion that only 5.1 billion tons of water were used out of the annual average precipitation of 110 billion tons. According to their survey, the nation had enough water on its lands but had failed to utilize it fully. They deemed dam constructions necessary for "national progress," while simplifying the river as merely a water supplier. Hydrological engineering consequently generated an abstract world where technological intervention to the natural environment leads to the prosperity of human society.

However, dam building resulted in redistributing resources among different social populations rather than bringing in resources from the natural world separated from human society. Noise and pollution from the construction sites ruined local agricultural businesses. Dam construction forcefully dislocated people in rural areas and restricted rural economic activities to protect the quality of water stored in reservoirs. Although rural populations suffered, dams prevented floods and supplied water to the cities downstream. Accordingly, dam building sought to redistribute resources rather than merely modify the natural world for social welfare. Examining the hydrological expertise that evolved out of colonialism, Cold War politics, and postcolonial nation-building leads us to understand human politics and values inscribed in this modern riverscape.

\section{References}

Ahn K (1991) Naui chwimi [My hobby]. Taehant'omok'ak'oeji [Journal of the Korean Society of Civil Engineers] 39(2): 8

Combined Economic Board (1958) Land Reclamation in Korea. Seoul

Frioux S (2014) Environmental History of Water Resources. In: Agnoletti M, Serneri SN (eds) The Basic Environmental History. Springer, pp 121-141 
Kim C (1969) Sujawŏn Kaebal Kyehoek Suribe P'iryohan Sumun Yŏn'gubangbŏp [Hydrological Research Methods for Planning Water Resources Development]. Ministry of Construction, Seoul

Korea Water Resources Development Corporation (1968) 1968 Corporation Photo Album, Seoul

KTV (1967) Kŏnsŏrŭi meari [Echoes of construction]. KTV, Korea

Mauch C, Zeller T (2008) Rivers in History and Historiography: An Introduction. In: Mauch C, Zeller T (eds) Rivers in History: Perspectives on Waterways in Europe and North America. University of Pittsburgh Press, Pittsburgh, pp 1-10

Schönach P (2017) River histories: a thematic review. Water History 9(3): 233-257

Smith Hinchman \& Grylls Associates (1960) Feasibility Study of Hydro Sites on South Han River Part IChungju Hydroelectric Project. Smith, Hinchman \& Grylls Associaates, Inc., San Francisco

UNC Economic Coordinator (1959) OEC Representatives on River Basin Committee. Office Memorandum, RG 469, Subject Files (1954-1961), Box 7, NARA (College Park)

Von Seggern ME, Callahan JT, MacMillan WF (1965) Report of Preliminary Survey Han River Basin, Republic of Korea. Washington, D.C.

\section{What is a River Historian?}

\section{Scot McFarlane}

I had originally planned to present at the April 2020 ASEH conference along with the May 2020 River Rally conference. I am currently collaborating with several environmental organizations on river history through webinars and digital history projects.

Last spring, Ramya Swayamprakash and I had planned on creating a discussion on the role of river history for our workshop, "The Power of Hidden River Histories," at River Rally, a conference for river conservationists in the United States. Unfortunately, not only did COVID prevent us from presenting in person, but we also had to prerecord our workshop on zoom without a live audience, thwarting our attempt at greater interactivity. Nonetheless, we modeled the value of different perspectives on river history: Ramya emphasized the ways in which river history can inform policy and I argued that it could allow conservation groups to reach more people by showing rivers' relationship with our history. Together, we tried to showcase basic skills that apply to historical research while reminding our audience that they already had the experience and authority to share their own river's history. Over the past two decades, environmental historians have largely focused on the ways in which people are a part of nature, a concept that might help environmental activists chart a clearer path towards environmental justice. The rapid changes in the politics of climate change have further highlighted this point-regardless of other factors, the increased rainfall leading to flooding rivers cannot be said to lack a human influence. How can rivers and the stories we tell about them become more than just markers of looming tragedy? Rivers represent the change that defines the study of history and are thus well suited to bring together historical analysis and environmental justice.

For the past year and a half, I have collaborated with a number of scholars and conservationists on my first attempt to make the role of a river historian into something distinct from academic research through a public history project: Confluence: The History of North American Rivers (riverhistories.org). I received several small grants that paid for hosting fees and colorful river maps created by Robert Szucs of Grasshopper Geography. The goal of the project is to present river histories across the continent as individual storymaps that will allow people to learn about their home river and compare it with other rivers. These storymaps have served as a starting point for interactive events in the new virtual world created by the pandemic. This summer, I co-led a digital history walk of the Harlem River 
in which we accommodated many more people than would have been possible had we held the event in-person (as it was originally planned). Likewise, this fall I have organized an online conference titled, "All Water Has a Memory: Rivers and American History" that brings together academics, nature writers, conservationists, and community activists to explore the purpose of river history for our present moment. As rivers cut across geographic and social boundaries, they have the potential to connect new groups of peoplethe turn to virtual spaces means that we can discover these histories collectively and with a common purpose that is not limited by who can afford to travel to a particular conference.

My quest to define the title of river historian has taken on the urgency of needing employment once I defend my dissertation next spring. How would such a role bridge the worlds of environmental activism and academia? And how would an organization justify the salary of a river historian outside of a university? The American Historical Association's career diversity initiative has shown the value of a history $\mathrm{PhD}$ for a wide range of occupations, but their efforts have largely highlighted preexisting jobs rather than those focused on historical analysis. ${ }^{1}$ How might future historians have more agency in creating new jobs and new roles as storytellers? Over the past year I have come to realize that naming oneself a river historian means spending most of your time explaining what your title means, but river history itself is widespread even if understudied outside college classrooms.

The text and approaches to river history that make clear connections to the present and future, best support environmentalist's efforts to center environmental justice in their work. The landscape architect Ann Whiston Spirn's project in the Mill Creek neighborhood of Philadelphia suggests the promise of river history to connect communities with a better present and future. Spirn led a movement to teach public school students the history of their neighborhood through reading their landscape in the 1990s and early 200s. They learned about the ways in which urban planners willfully covered up and ignored the flow of Mill Creek, a decision that led to flooding and degraded housing stock. Though the creek had become a liability for the neighborhood, the students also explored the ways in which it could also be a potential resource for the community. This landscape literacy empowered students to take action and lobby politicians to make improvements that addressed these historical injustices to people and place (Spirn 2005).

Recently I had the opportunity to speak with environmental activists directly about the purpose of river history. They are curious about its potential, but they are also overstretched. They need the "so what?" question answered concisely and with metrics to back up my claims. I can point to earlier examples of river history's success, such as how the Rivers of America series published in the middle of the twentieth century included a number of bestsellers and Pulitzer Prize winners (Mink 2006). Most environmental organizations already incorporate history into their narrative of their rivers, mainly focused on pollution and an often-triumphant cleanup. As more of these groups begin to center environmental justice in their work, river history provides an opportunity for them to tell a more specific story that explains the ways in which the costs of pollution were unevenly distributed. River history could help these environmental organizations to reach a wider range of people by showing how we are connected through narratives of resistance and

\footnotetext{
1 The AHA has an extensive list of publications and programs on its career diversity initiative at: www. historians.org/career-diversity
} 
resilience. In this moment of COVID and Black Lives Matter, collaboration between conservationists and historians has the potential to bring environmental justice into the center of the environmental movement.

\section{References}

Mink, Nicolaas (2006) "A Narrative for Nature's Nation: Constance Lindsay Skinner and the Making of Rivers of America," Environmental History 11, no. 2 751-774.

Spirn, Anne Whiston (2005) "Restoring Mill Creek: Landscape Literacy, Environmental Justice and City Planning and Design," Landscape Research 30, no.3, 395-413.

\section{Protecting the ship and the coast: testing the limits of technological adaptation during the Dutch shipworm epidemic of the 1730 s}

\section{Adam Sundberg}

This is the precis of a conference paper that was to be presented at the 2020 Water History Conference in Delft. It applies an envirotech approach to the history of dike adaptation during the Dutch shipworm epidemic of the 1730s, incorporating the broader context of Dutch maritime experience with the mollusk. I had hoped for conference feedback on my methods as I expand the project for submission to an edited volume on early modern disasters.

In 1730, Dutch dike authorities discovered a hitherto little-known species of shipworm (Teredo navalis) in the wooden piles, revetments, and breakers that protected coastal dikes. $^{2}$ The wood-boring mollusk carved cavities into these structures, which fractured and broke following even minor storms. Further investigation revealed infestation across three provinces. By 1732, the threat of widespread dike failure prompted a crisis in water management that assumed existential proportions. This was the first large-scale outbreak of shipworms in Dutch waters. Dike officials labelled the shipworm a novel threat and descriptions of the shipworm 'plague' in popular media emphasized its 'strange' and 'previously unknown' character. This language of novelty was an important motivation to adapt dike designs. (Sundberg 2016) Lacking time-tested solutions and fearing disaster if dikes failed, authorities enacted capital-intensive dike reconstruction programs, in many cases replacing wooden components with imported stone.

\footnotetext{
2 "Notulen van de Staten (en Gecommitteerden van de Breede Geërfden), 1511-1812". November 23, 1730.
} 


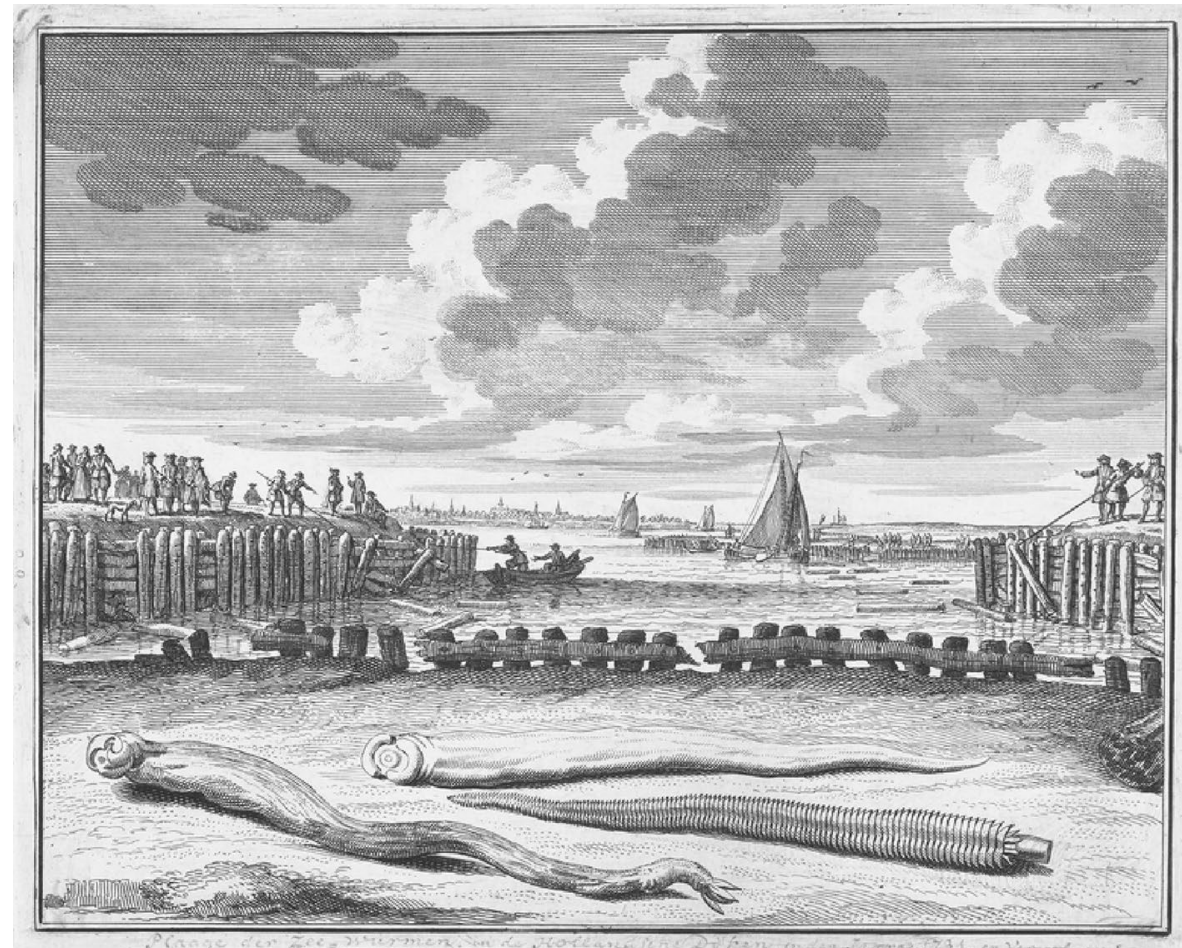

Fig. 2. The discovery of shipworms in the 1730s prompted immediate repair work to Dutch dikes, sluices, and harbors. Prints of the outbreak featured detailed renderings of the mollusk, which at the time remained little understood outside maritime experience, as well as vignettes of those repairs. Abraham Zeeman, Paalwormen die de dijkbeschoeiïngen aantasten, 1731. Rijksmuseum. Amsterdam. ca. 1731-1733. http://hdl.handle.net/10934/RM000 1.COLLECT.479007

This transformation is well known in Dutch water history and considered a pivotal moment in dike modernization. (Baars 1989; Van de Ven 2003) Histories of Dutch dike adaptation embrace the catalytic role of shipworms in these changes, yet little scholarship explores the process of adaptation, the broader context of Dutch experience with the mollusk, or the influence of the species on envirotechnical systems. Shipworms were a primary hazard of oceanic travel throughout the early modern period and mariners had coped with them for centuries. Although dike authorities in the 1730s often emphasized the novelty of the threat, they nevertheless proposed, tested, and implemented shipworm 'remedies' derived from this maritime knowledge. These trials operated at the nexus of two largely distinct envirotechnical systems-maritime shipbuilding and coastal water management. The common threat of shipworms temporarily bridged these systems and encouraged the diffusion of technical knowledge.

The shipworm pandemic of the 1730s is a useful subject of envirotechnical analysis both because it reflects key contributions of the field and moves the discussion into new territory. The synthesis of environmental history and the history of technology has encouraged richer interpretations of the ways that technologies mediate human-environmental 
interactions. (Pritchard 2014; Reuss and Cutliffe 2010; Jørgensen et al. 2013) Technologies facilitated environmental manipulation, motivated practical and scientific understanding of environments, influenced environmental decision making, and were in turn shaped by those environments. This synthesis likewise encourages greater consideration of the role of environments, and more recently animals, as active agents of change within large technological systems. (Jørgensen 2014; Benson 2015) Human actors and institutions co-produced these systems through historically inscribed envirotechnical regimes. Finally, envirotechnical analysis has recently moved into the realm of disaster history. Interpreting calamity through an envirotechnical lens highlights the convergence of natural and sociotechnical processes in both the creation of high-risk systems, as well as the response to their catastrophic failure. (Pritchard 2012; Knowles 2014)

The shipworm epidemic of the 1730s showcased these insights. Early modern dike infrastructure and shipbuilding were each envirotechnical systems that emerged out of their respective social, cultural, and physical environments. (Law 1987; Van Dam 2002; Soens et al. 2019) Technological changes in both responded to a diverse array of interconnected human and non-human influences, whether property relations and institutional decisionmaking, or coastal erosion and mollusks. Likewise, the shipworm epidemic of the 1730s was an envirotechnical disaster. It reflected the long history of technological and institutional innovation in Dutch flood defense and the transformation of coastal environments. It also influenced later adaptations in dike building regimes.

The shipworm epidemic also revealed the important role that environments played in the transfer of technology. Since all technologies emerged in specific social and physical environments, dissemination often demanded adaptation to accommodate new conditions. Environments, thus, act as a buffer that limits transfer. Scholarship on the evolution of large technical systems have long acknowledged this relationship, although environments have rarely occupied a central or dynamic position in this work.(Hughes 1987) More recent efforts have begun investigating the role that environmental differences played in the transfer of technical knowledge between European and colonial environments. (Davids 2019) This work focuses on the transfer of technologies across political borders and vast distances. It also privileges an interpretation of environments as barriers to diffusion. The shipworm epidemic affords a unique perspective on the transfer of technology not just within one state, the Dutch Republic, but across envirotechnical systems. Elements of the non-human environment, including the shipworm animal, operated as both bridge and barrier to this transfer during the 1730 s.

Shipworms catalyzed an envirotechnical disaster that forced water management officials to expand the scope of input into their responses. This reduced barriers to communication and encouraged transfer of technical knowledge. Dike officials sought advice from the public, natural historians, and experts in water management across the Dutch Republic. (Sundberg 2015) It also encouraged closer dialogue with shipbuilding. For over a century, Dutch shipbuilders had fashioned a suite of technologies to mitigate or combat the threat of shipworms, ranging from paints and sacrificial hulls, to oxidized nails and metal sheathing. (Van Duivenwoorde 2015; Bartels et al. 2015) Dike officials experimented with these strategies and, in the process, rediscovered their limitations.

In ordinary conditions, maritime shipbuilding and coastal dike engineering operated as largely separate systems composed of distinct social and ecological elements. The crisis of the early 1730s, however, presented a unique moment when shipworms bridged that gap. My work on this subject, which will be expanded into a chapter for an edited volume on early modern disasters, explores the challenges shipworms presented both 
dikes and ships, the limitations of translating maritime adaptations to the coasts, and dike authorities' ultimate decisions to accept or reject these strategies.

By the 1730s, the weaknesses of maritime adaptations were accepted as a manageable cost of work at sea. The existential character of the shipworm threat on the coast, however, forced dike authorities to opt for a more radical transformation of their flood infrastructure. Over the next two decades, dike authorities across the Republic adapted their dikes. This process was asymmetric, with several regions retaining use of alternate strategies, including several developed for ships. Most strategies, however, worked to separate wood from water, either by buffering or replacing wooden dike components with stone. (Baars 1990; Fransen 2011; Bartels 2016) Dike officials thus modified their coastal environments in a manner that shipbuilders could not hope to match. Shipworms may have bridged these envirotechnical systems, but dike adaptations ultimately leveraged their environmental differences.

\section{Archival References}

Zeeuws Archief, MS 3000.20. Notulen van de Staten (en Gecommitteerden van de Breede Geërfden), 1511-1812.

\section{Printed References}

Baars C (1989) Het dijkherstel onder leiding van de Staten van Holland. Waterschapsbelangen 74:196-204

Baars C (1990) Nabeschouwingen over de paalwormplaag van 1731/32 en de gevolgen daarvan. Waterschapsbelangen 75:504-509

Bartels M (2016) Het Bolwerk Tegen de Woede van de Zee. In: Bartels M (ed) Dwars Door de Dijk: Archeologie En Geschiedenis van de Westfriese Omringdijk Tussen Hoorn En Enkhuizen. Stichting Archeologie West Friesland, Hoorn, pp 122-175

Bartels MH, Swart P, De Weerd H (2015) Wormspijkers in het Medemblikker havenhoofd: Archeologisch en historisch onderzoek naar de maatregelen tegen de paalworm in het noordelijk havenhoofd van Medemblik, West-Friesland, NL. West-Friese Archaeologische Rapporten 80

Benson E (2015) Generating Infrastructural Invisibility: Insulation, Interconnection, and Avian Excrement in the Southern California Power Grid." Environmental Humanities 6:103-130

Davids K (2019) Hydraulic Experts and the Challenges of Water in Early Modern Times. In: Soens T, Schott D, Toyka-Seid M, De Munck B (eds) Urbanizing Nature: Actors and Agency (Dis) Connecting Cities and Nature Since 1500. Routledge New York, pp 179-196

Fransen A (2011) Dijk onder spanning: De ecologische, politieke en fianciële geschiedenis van de Diemerdijk bij Amsterdam, 1591-1864. Uitgeverij Verloren, Hilversum

Hughes T (1987) The Evolution of Large Technological Systems. In: Bijker W, Hughes T, Pinch T (eds) The Social Construction of Technological Systems: New Directions in the Sociology and History of Technology. MIT Press, Cambridge, pp 45-76

Jørgensen D, Jørgensen FA, Pritchard SB (eds) (2013) New Natures: Joining Environmental History with Science and Technology Studies. University of Pittsburgh Press, Pittsburgh

Jørgensen D (2014) Not by Human Hands: Five Technological Tenets for Environmental History in the Anthropocene." Environment and History 20:479-489

Knowles SG (2014) Learning from Disaster? The History of Technology and the Future of Disaster Research. Technology and Culture 55:773-784

Law J (1987) Technology and Heterogenous Engineering: The Case of Portuguese Expansion. In: Bijker W, Hughes T, Pinch T (eds) The Social Construction of Technological Systems: New Directions in the Sociology and History of Technology. MIT Press, Cambridge, pp 111-134

Pritchard SB (2012) An Envirotechnical Disaster: Nature, Technology, and Politics at Fukushima. Environmental History 17:219-243

Pritchard SB (2014) Toward an Environmental History of Technology. In: Andrew Isenberg (ed) The Oxford Handbook of Environmental History. Oxford University Press, Oxford, pp 227-258 
Reuss M, Cutcliffe SH (eds) (2010) The Illusory Boundary: Environment and Technology in History. University of Virginia Press, Charlottesville

Soens T, De Block G, Jongepier I (2019) Seawalls at Work: Envirotech and Labor on the North Sea Coast before 1800. Technology and Culture 60: 688-725

Sundberg A (2015) Floods, Worms, and Cattle Plague: Nature-induced Disaster at the Closing of the Dutch Golden Age, 1672-1764.” Dissertation, University of Kansas

Sundberg A (2016) An Uncommon Threat: Shipworms as a Novel Disaster. Dutch Crossing 40:122-138

Van Dam PJEM (2002) Ecological Challenges, Technological Innovations: The Modernization of Sluice Building in Holland, 1300-1600. Technology and Culture 43:500-20

Van de Ven, GP (2003) Leefbaar Laagland: Geschiedenis Van De Waterbeheersing En Landaanwinning in Nederland. Uitgeverij Matrijs, Utrecht

Van Duivenvoorde W (2015) Dutch East India Company Shipbuilding: The Archaeological Study of Batavia and Other Seventeenth-Century VOC Ships. Texas A\&M University Press, College Station

\section{The ICOMOS ISC water and heritage}

\section{Tino Mager}

This article presents the new ICOMOS International Scientific Committee (ISC) on Water and Heritage. The ISC's aim is to bridge the worlds of heritage and water to bring heritage experience and knowledge into planning, engineering and policy making. This paper had been planned for the IWHA conference in Delft, and a version was presented at the shortened online format of the ISC meeting at Delft.

In 2012 the Dutch section of the International Council of Monuments and Sites (ICOMOS NL) launched an initiative on Water and Heritage for the Future. It has since gained international momentum by supporting the dialogue between water and heritage organisations. The initiative's goals are (1) to unlock the knowledge that can be gained from waterrelated heritage in order to showcase its significance, (2) to incorporate it in the present, to combine it with current technologies and management strategies for an improved water future, and (3) to bring together heritage experts, water engineers, and policymakers. The motivation for this was fed by an increasing interest in The Netherlands for water-related cultural heritage (see e.g. the Manual Water, Heritage and Environment by the Cultural Heritage Agency of the Netherlands (RCE), the activities of the WaterHeritage network or organisations like Het Limburgs Landschap or Historische Vereniging Die Goude) ${ }^{3}$. They demonstrate that water-related cultural heritage should be considered as significant and adaptable to all current and upcoming water management challenges.

During the 2019 International Conference Water as Heritage in Chiayi (Taiwan), it was decided to purposefully work towards the creation of an international platform for networking, education, and dialogue on the importance of water heritage in the form of an International Scientific Committee (ISC) of ICOMOS. The proposal for such a committee had been presented already at a meeting of the ICOMOS Scientific Council in December 2017 in Delhi (India) and has since received broad support. The overall aim of the ISC is to improve the future of water by integrating water heritage in community engagement, technology, and policymaking. In addition to the necessary formal steps, a contextual specific focus is placed on the following aspects:

\footnotetext{
${ }_{3}$ https://www.cultureelerfgoed.nl/publicaties/publicaties/2018/01/01/manual-water-heritage-and-envir onment; http://waterheritage.nl; https://www.limburgs-landschap.nl/; https://www.diegoude.nl/werkgroepe $\mathrm{n} /$ watergilde/
} 
- The development of specific methodologies that serve as a basis for the development of policies and design processes considering the importance of cultural heritage in the water world.

- The presentation and promotion of best practice examples for the management of water heritage.

- To discuss and develop communication and links between the ICOMOS ISC with water managers, designers, planners, and relevant organisations.

The proposed ISC is to fill the disciplinary and institutional gap as there is still no international cultural heritage organisation explicitly dedicated to water-related heritage. Nor is there any major water organisation that considers heritage to be a major asset for water management. The ICOMOS ISC should set up working linkages with several international water organisations, such as the International Water History Association that is dedicated to historical aspects. And within ICOMOS it cooperates with several other ISCs like Archaeological Heritage Management (ICAHM), Cultural Landscapes (ISCCL), International Scientific Committee on Risk Preparedness (ICORP), Intangible Cultural Heritage (ICICH), and Places of Religion and Ritual (PRERICO), among others. They do not explicitly deal with the water aspects, but, just like other ISCs, include them in their specific work. Further, cooperation will be sought with the International Committee for the Conservation of the Industrial Heritage (TICCIH), a designated consultant to ICOMOS, touching on water industry heritage (Douet, 2018). Outstanding bridging initiatives with specific interests are the above- mentioned Ramsar Cultural Network and the Global Water Museums Network. Heritage approaches such as Historical City Landscapes also naturally touch on water issues, but they are not explicitly focused on this topic. On the other hand, assessment tools, such as hydrobiographies that are being developed modelled on the landscape biography, have not yet reached universal recognition (Beek \& Kooiman, 2014; Bosch \& Soré, 2016).

Two international water organisations show increased interest in cultural heritage, the International Water Association (IWA) — especially through the Specialist Group on Water in Ancient Civilizations - and the International Commission on Irrigation and Drainage (ICID) through the World Water System Heritage Programme and the Working Group on History of Irrigation, Drainage, and Flood Control. While the World Water Council has only once (Kyoto 2003) addressed cultural heritage at the World Water Forum, there are clear tendencies towards recognition of the importance of the issue-e.g. the World Water Week 2019, organised by the Stockholm International Water Institute, hosted a session on water and heritage. Also on 3 February 2020, the United Nations Centre for Regional Development (UNCRD), the National Graduate Institute for Policy Studies (GRIPS), the High-Level Experts' and Leaders' Panel on Water and Disasters (HELP), and the International Council on Monuments and Sites (ICOMOS), Netherlands, held an international symposium titled 'Water and Culture: Learning from Water Heritage to Innovate Regional Development' in Tokyo.

The proposed International Scientific Committee on Water and Heritage will be dedicated to the research, protection, and promotion of water-related cultural heritage and its material, conceptual, political, and spiritual aspects. The aim is to improve comprehension and dissemination of the knowledge and experience contained in the world's water heritage and harness it to sustainably address the water-related concerns of the present and future. Specifically, the objectives are to create an international platform for interaction between ICOMOS, its ISCs, and other heritage organisations and the water sector; to forge a connection between governments, agencies, associated communities, and NGOs for 
networking, education and dialogue about the significance and management of water heritage; and moreover, to develop methodologies, training, policies, good design processes, responding to traditional wisdom; to inform climate change mitigation and adaptation; to improve current and future water management and planning; and generally, to strengthen the role of water heritage in social engagement and policymaking. ${ }^{4}$

This brief introduction to the upcoming ISC is accompanied by a call for membership aimed at heritage experts, but especially at water engineers, planners and policymakers, in order to establish and continue the dialogue between the disciplines in a targeted manner.

\section{Bibliography}

Beek, M. \& Kooiman, M. (2014). Hydrobiografie Marken-Leven met het water. Arnhem: Land-id.

Bosch, J. W. \& Sorée, C. (2016). Hydrobiografie Schelde-estuarium. Den Haag: College van Rijksadviseurs.

Douet, J. (2018). The Water Industry as World Heritage-Thematic Study. TICCIH, 2018. URL: https://ticcih.org/wp-content/uploads/2018/05/TICCIH-Water-Report.pdf

Hein, C., van Schaik, H., Six, D., Mager, T., Kolen, J. C. A., Ertsen, M., Nijhuis, S., Verschuure-Stupi, G. (2019b). Introduction: Connecting Water and Heritage for the Future. In: Hein, C. Adaptive Strategies for Water Heritage -Past, Present and Future. Cham: Springer, pp. 1-17.

ICOMOS NL. The Statement of Amsterdam. 2015. URL: https://www.icomos.nl/media/ Water_and_Heritage/Final_Statement_Protecting_Deltas_Heritage_Helps.pdf

Mager, T. (2020). Water Heritage-Global Perspectives for Sustainable Development. Taichung: BOCH.

Willems, W., Schaik, H. van, eds. (2015). Water \& Heritage: Material, Conceptual and Spiritual Connections. Leiden: Sidestone.

\section{Citizen participation for water heritage in a built environment}

\section{Arie den Boer}

In this short paper, which I intended to present at the 2020 Delft Water History Conference, I had planned to share a part of my PhD project at Erasmus University Rotterdam. My thesis focuses on citizen participation for water heritage in the built environment. Using the water system of the Alblasserwaard as an example, I wanted to explore how that resource system can be seen as non-excludable and rivalrous (terms from Elinor Ostrom). The water system is in a major transition due to climate change, and I wanted to analyze the negotiations concerning common resources in a polycentric arena.

\footnotetext{
${ }^{4}$ Paragraph based on the ISC Water and Heritage draft Mission Statement, compiled by the ISC Task Force. See also: http://www.water.icomos.org.
} 


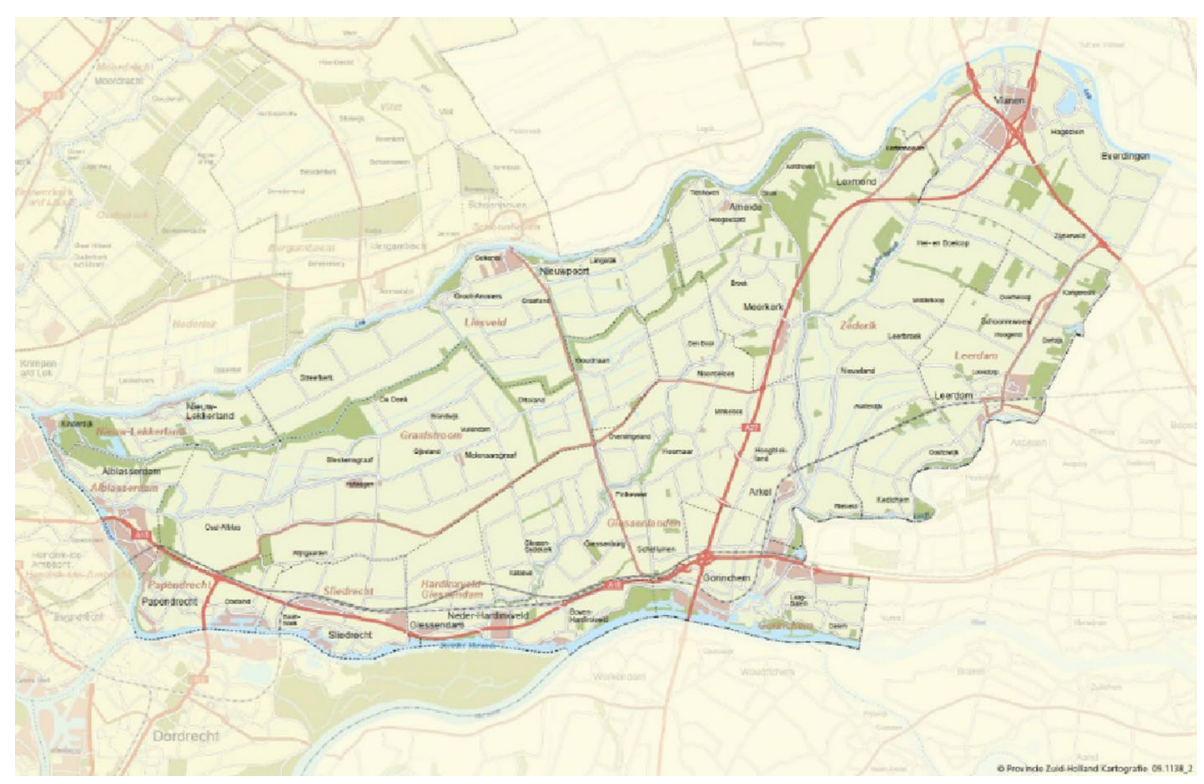

Fig. 3. Provincie Zuid-Holland Kartografie 09.1138_2

\section{Alblasserwaard}

Alblasserwaard is a Dutch region in the south-east of the province of South-Holland. With an area of some $250 \mathrm{~km}^{2}$, the region includes 170.000 inhabitants (or 680 per $\mathrm{km}^{2}$ ) (Waterschap Rivierenland 2016). It is bordered in the north by the province of Utrecht, to the west by the city of Rotterdam and to the south-west by the city of Dordrecht. Today, Alblasserwaard is surrounded by an enclosing dike (which is registered as "diked area 16" in the national register) (Vergouwe, Van den Berg, and Van der Scheer 2013). The landscape of Alblasserwaard can be characterized as a peatland below sea level. The Waard is sliced by ditches and streams plus the two peat rivers Alblas and Giessen. The Alblas used to flow into the Noord river, whereas the Giessen ended in the Beneden-Merwede river. As far as we know now, the first more permanent human settlements in Alblasserwaard date from the end of the 10th century. Especially in the course of the 13th century, habitation increased. Those human settlements had to fight an uphill battle against high floodwaters and flood surges (Boersma 1939). First evidence of reclamation activities, including creating polder areas, is found in a Charter from Count Floris V (24 June 1254-27 June 1296), Count of Holland and Zeeland, dating from March 31st 1277.

\section{Drainage developments}

Due to further peat oxidation, settling and rising river levels due to sea level rise, the regional water system needed water storage for times that natural discharge to the river was impossible. In 1365 and 1369, two large canals were dredged to obtain a better discharge. One canal drained the Overwaard, the other the Nederwaard. Both canals merged into the Lek river at Elshout, which is the lowest spot of Alblasserwaard. In 1738 and 1740, 
sixteen windmills were built, equally distributed between Overwaard and Nederwaardwhich each had their own water board. The windmills pumped the water from the low belt canal system to the higher belt system, which stored the water until river levels were low enough for natural discharge under gravity. Today, these 16 windmills are the largest group of windmills in the Netherlands. In 1997, they were added to the UNESCO World Heritage list (Groeneboer et al. 2016). In order to strengthen the pumping capacity, two steam pumping stations were built in 1868 for Nederwaard (Van Haaften) and Overwaard (Wisboomgemaal). Until 1950 onwards, the windmills remained active. After 1950, the function of the windmills was taken over completely by motor-powered pumping stations. Today, the J.U.Smit diesel engine pumping station (built in 1972) takes care of draining Nederwaard. Electric pumping station Ir. G.N.Kok (built in 1995) takes care of Overwaard. It is also possible to let river water flow back into the Waard during dry seasons.

\section{The research project}

The water system is continuously under review (Schengenga and Bennink 2014). Until recently, the main idea of the authorities involved was that the water system could be adapted with the same canal infrastructure through modernization and transformation, like the changes that we observed from the original windmills, through steam engines, diesel engines and electric engines to drive pumps. Within the discussions on climate change, in 2018 the regional water authority Waterboard Rivierenland (WSRL) launched the planning process to develop a robust and a climate proof water system. This process included exploration of options and wishes with other authorities, citizens, civil society organizations and businesses. The process was labelled as a new beginning for an iconic polder: a new vision for 2050 for the water system in Alblasserwaard. The main idea was to develop a futureproof arrangement of the water system through an adaptive implementation strategy with clear participation of authorities, citizens, civil society and businesses. In my research project, I aim to answer the question what the impact of citizens' participation for water heritage in a built environment like Alblasserwaard would be. Answering this question is a step to develop a framework for organizing citizen participation for water heritage in built environments in general.

\section{Theoretical background}

In the planning stage, the waterboard organizes meetings in which all stakeholders participate, including citizens. In a way, the water system becomes a common pool resource through such meetings, a common good, set between private and public goods, rivalrous and non-excludable. Elinor Ostrom has developed the Institutional Analysis and Development (IAD) framework for collective action and collective governance. The framework defines exogenous variables, action arena, interaction and evaluative criteria for an outcome and a fast feedback loop to the action arena and a slow feedback loop to the exogenous variables. It is based on rules, norms and shared strategies for institutions engaged in collective action and collective governance (McGinnis 2011). Ostrom has defined eight design principles for an action arena where actors meet for action situations to work (Chow and Weeden 2012). An extension to the IAD framework is the Social-Ecological System (SES) concept in its simplest form with resource units, resource system, governance and users that interact under social, economic and political settings. When applying these ideas, 
it is clear that a framework for Alblasserwaard becomes rather complicated, as it consists of many interacting SES's. Resource units are dikes, pump stations, water locks and weirs, to name just a few. The water system of Alblasserwaard itself is a resource system, but it consists of many sub-systems, which for example belong to a municipality or a landowner. The water system of Alblasserwaard is governed by WSRL, but this authority has to deal with other public and private institutions, who have a delegated governance function. Nevertheless, the SES concept appears to be a good starting point for organizing collective action and governance.

\section{First findings}

WSRL calls the vision 2050 an integral vision of water management. In first instance, the planning focuses on the core tasks of WSRL. At a later stage, participation follows with other stakeholders, to discuss these tasks and provide a wider perspective. This is all envisioned in the planning agenda (Waterschap Rivierenland 2017) (Waterschap Rivierenland 2018) (Waterschap Rivierenland 2020). The water system itself covers a large territory. The Waterboard organizes participation meetings for all stakeholders of the territory, or for a particular area where a pump station, weir and lock is planned. This means that it is WSRL who defines the resource system and resource units. After this initial stage, the stakeholders including citizens are invited to participate. This is called top-down citizen participation. The action arena with action situations and actors is set by the water board (local government). The evaluative criteria are also defined and set by WSRL. These initial definitions and proposals are discussed with different stakeholders. Without claiming to provide a complete overview, some examples of stakeholders and their positions provides more detail on the type of debate and engagement one could expect in these planning processes.

The World Heritage Kinderdijk Foundation (Stichting Wereld Erfgoed Kinderdijk) (SWEK) has a clear interest in the water system discussions. A major change that is explored in Vision 2050 concerns the drainage of Giessenlanden. Currently, Giessenlanden is drained through the Achterwaterschap canal, part of the lower belt system in Overwaard. This route for the water is rather long, and as such vulnerable for downpours and strong west winds. The future lower belt canal in Overwaard would have the same level of the lower belt canal of Nederwaard, which means that these two canals start serving the same territory. However, this means that the level of the Overwaard canal will drop, which has an impact on the pumping conditions of the eight windmills of Overwaard. This is an important issue for a world heritage complex like Kinderdijk which has to have outstanding universal values and meet many selection criteria (Centre 2020). The interests of Kinderdijk are supported, among others, by the Cultural Heritage Agency of the Netherlands (RCE), the Millers Organization of Overwaard. Kinderdijk also aims to cooperate closely with the Province of Zuid-Holland and local municipalities Alblasserdam and Molenlanden, each with their own heritage policies.

Another interest that is worth discussing is recreation, which is linked to the same discussion as mentioned above. In Vision 2050, the lock in Middelkade will be removed as the level of Nederwaard and Overwaard canals is to be made equal. A new lock would separate Giessenlanden from Nederwaard. The Consultative Body Water sport Alblasserwaard (Overlegorgaan Watersport Alblasserwaard (OWA)) represents four watersports associations in Alblasserwaard, one of which would have to move due to the construction of a new pumping station, which requires broadening of the feeder canal. 
This option also will impact a well-developed nature reserve with high values in terms of landscape, day recreation, living pleasure, and even agriculture. This has the interest of the Environmental Service Haaglanden (Omgevingsdienst Haaglanden), Staatsbosbeheer (commissioned by the Dutch government to strengthen the position of nature in the Netherlands), Nature and Birdwatch Alblasserwaard (Natuur en Vogelwacht Alblasserwaard), and agricultural and horticultural organizations.

\section{Final remarks}

It is a challenge to arrange the planning process for Vision 2050 to arrive at a result that is acceptable in a way to all stakeholders involved. At least, all stakeholders are heard and can comment and are offered other opportunities to engage during participation meetings, which are held within the decision-making process of the waterboard. Often, the citizens that take part in the meetings are member of an interest organization. Naturally, each stakeholder brings its wishes and concerns forward. It also helps to inform stakeholders at an early stage about the decisions to be taken into account for their organizations. Despite all these critical issues, the collective action of WSRL to bring Vision 2020 forward has obtained a lot of credit and support. For many stakeholders, the complex governance of a water system is an eye-opener.

\section{References}

Boersma, Piet. 1939. Alblasserdam's Heden En Verleden. In Honderd Opstellen Beschreven. Herdruk 1974. Alblasserdam: Europese Bibliotheek-Zaltbommel. https://resolver.kb.nl/resol ve?urn=MMKB06:000005513:pdf.

Centre, UNESCO World Heritage. 2020. “The Criteria for Selection.” UNESCO World Heritage Centre. 2020. https://whc.unesco.org/en/criteria/.

Chow, T, and B Weeden. 2012. "An Introduction to Ostrom's Eight Principles for Sustainable Governance of Common-Pool Resources as a Possible Framework for Sustainable Governance of Space." https://swfound.org/media/61531/isusymposium2012paper_tchowbweeden.pdf.

Groeneboer, Saskia, Iris Van Meer, Isabelle Paz Soldan, and Jan Vredenberg. 2016. Werelderfgoed Kinderdijk: molens, water en gemalen. https://erfgoedstem.nl/molenwereld-kinderdijk-elshout/.

McGinnis, Michael D. 2011. "An Introduction to IAD and the Language of the Ostrom Workshop: A Simple Guide to a Complex Framework for the Analysis of Institutions and Their Development." SSRN Scholarly Paper ID 1762685. Rochester, NY: Social Science Research Network. https://paper s.ssrn.com/abstract $=1762685$.

Schengenga, Pieter, and Astrid Bennink. 2014. "H+N+S Landschapsarchitecten-Inrichtings-Plan Molenkade.” H+N+S Landschapsarchitecten. 2014. http://www.hnsland.nl/nl/projects/inrichtingsplan-molen kade.

Vergouwe, R., M. C. J. Van den Berg, and P. Van der Scheer. 2013. "Veiligheid Nederland in Kaart 2; Overstromingsrisico Dijkring 16 Alblasserwaard En de Vijfheerenlanden.” Consortium DOT.

Waterschap Rivierenland. 2016. "DE VAN DE ALBLASSERWAARD." https://www.waterschaprivierenla nd.nl/mgd/files/170703-03_bosatlas-watersysteem-alblasserwaard-gecomprimeerd.pdf.

Waterschap Rivierenland. 2017. "Een nieuw begin voor een iconische polder: Visie voor 2050 op het watersysteem in de Alblasserwaard." https://www.waterschaprivierenland.nl/mgd/files/visie-alblasserwaard2050.pdf.

Waterschap Rivierenland. 2018. "Gedeeltelijke herziening peilbesluit Alblasserwaard: Achterwaterschap.” Waterschap Rivierenland. Waterschap Rivierenland. $2018 . \quad$ / gedeeltelijke-herziening-peilbesluit-alblasserwaard-achterwaterschap. 
Waterschap Rivierenland. 2020. "Bijeenkomsten Alblasserwaard-Vijfheerenlanden.” Waterschap Rivierenland. Waterschap Rivierenland. 2020. /bijeenkomsten-alblasserwaard-vijfheerenlanden.

\section{A history of stepwells in India}

\section{Priyanka Sheth}

This essay presents a study on 'stepwells', which are deep stone-lined dug wells accessed at great depths by flights of steps and found extensively in the arid and semi-arid regions of Western India. By presenting the specific case of 'Jethabhai's stepwell' in south-eastern Ahmedabad, this essay offers a critique of conservation practices that lead to decontextualized musealization of water monuments. This essay was supposed to be presented at the South Asian Studies Association (SASA) 2020 Annual Conference in Rosemead, California. The next stage of this project is to revisit these the stepwell site and provide recommendations and examine the potential of design to re-integrate these structures in the contemporary urban context.

Water conservation systems have always been of paramount importance in the Indian subcontinent due to the seasonal nature of the monsoon rains, particularly in the arid and semi-arid regions, where rain is scarce (Narain and Agarwal 1997). The modification of the landscape for the collection, extraction, storage and use of surface water and groundwater became the defining characteristic of human settlements in these regions. Due to notions of purity and hygiene encoded in social practice, groundwater that had percolated and been filtered by the earth was privileged for drinking and cooking (Sheth, Jain and Tayyibji 2018). While ordinary dug wells are a consistent archetype across various geographies, the 'stepwell' is a type of well that is unique to the Indian subcontinent. A stepwell is essentially a large stone-lined well that taps into deep groundwater reserves where the water can be directly accessed by a user by descending subterranean flights of steps. Across the subcontinent, a variety of regional variations and formal configurations of the architecture of the stepwell can be found.

This essay focuses on the semi-arid region of Gujarat in Western India where we see the most architecturally elaborate and sculpted stepwells. Over a hundred known stepwells dating from the 7th century CE up to mid-19th century CE have been identified in the region. The typical stepwell from this region, colloquially known as a vaav, is a subterranean building consisting of a square, circular, or octagonal well shaft. This well shaft is accessible by a linear stepped corridor sandwiched between two parallel retaining walls that descends several storeys from the ground level. Some stepwells are further articulated with the addition of pillared pavilions at intermittent landings along the stepped corridor that providing spaces for pause and shade for weary travelers (Jain-Neubauer 1981). These spaces also served as social spaces outside of the domestic realm for women who performed the daily labor of fetching water, a practice that is common in parts of India even today (Mehta Bhatt 2014).

The authors were an integral part of a research and curatorial project called 'Stepwells of Ahmedabad' which was a joint effort led by a group of architects and students in 2016. This research, which documented 17 stepwells in the city, in their current state was displayed in multiple exhibitions in Ahmedabad in 2016 and at the Yale Architecture Gallery in 2018. Apart from presenting the architectural splendor of these structures, the exhibitions attempted to generate public as well as academic discourse on questions of water, 
settlement patterns, social relationships and conservation. The next stage of this project will be to revisit each of these sites and provide case-specific recommendations and potential design interventions for reinterpreting these stepwells in order to integrate them in contemporary urban contexts.
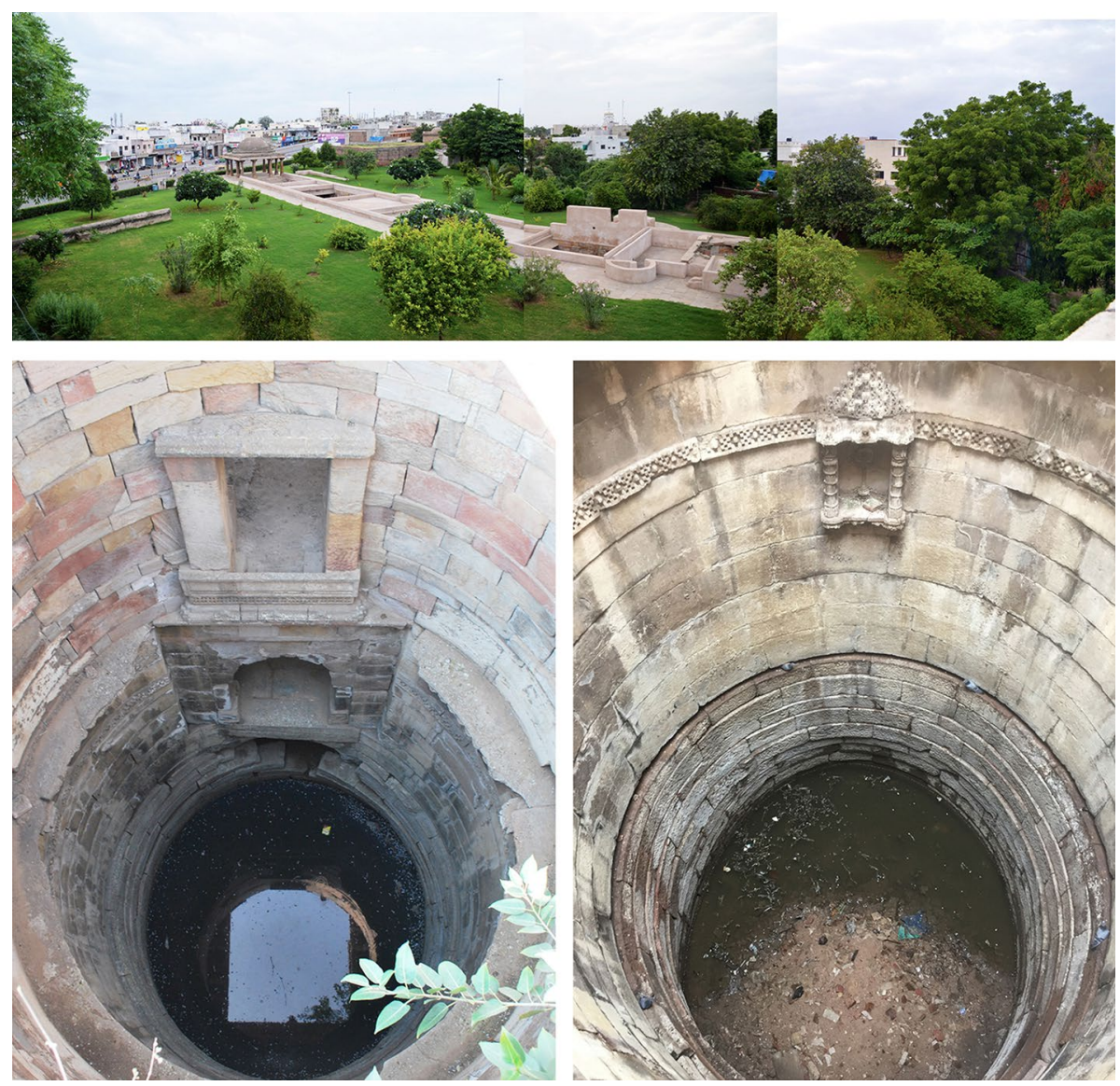

Fig. 4. (Top) A panoramic view of the Jethabhai's stepwell with the surrounding lawns in 2018. (Bottom Left) Water level in the well shaft as observed by the authors in 2016. (Bottom Right) The state of the well shaft in 2018 after it was filled with debris after the restoration. (All photographs by the authors)

\section{Stepwells of Ahmedabad}

Many of Gujarat's stepwells are found in Ahmedabad-an important historic trading center and now the largest city in the region (Jain-Neubauer 1981). Historically, the urban core of Ahmedabad was a dense, walled city occupied by the political and mercantile quarters. Water needs of individual households in the walled city were met by underground rainwater cisterns built between the foundations of individual homes or small dug wells (Mehta and Jamindar 2008). These systems defined the realm of private water; stepwells 
were more commonly found outside the walled city in the suburban areas, rural hinterlands and further along long-distance trade routes. They were the main shared source of water for hamlets or travelling caravans and were also used to water orchards and gardens. Inscriptions found in some of the larger and more ornate stepwells suggest that they were commissioned by royalty as well as noble men and women (Jain-Neubauer 1981). It seems likely that the more modest stepwells, where donative inscriptions are absent, may have been built by local communities.

Through fieldwork that surveyed 17 stepwells in and around Ahmedabad in 2016, we found that the current condition of these stepwells varied greatly. We came across a few stepwells that are celebrated and are registered as monuments of national importance by the Archaeological Survey of India (ASI). Among those without any official protected status, some are completely ruined while some are used by the locals to dump garbage. Interestingly, many stepwells that we surveyed are still actively used by the local community as sacred shrines for worship and have thus been re-integrated in the urban fabric, but with new meanings (Sheth, Jain and Tayyibji 2018). The most striking observation is that very few stepwells still held water. Across the subcontinent, many traditional water systems went out of use with the advent of centralized piped water supply and British colonial policies (D'Souza 2006). Starting in the early 19th century, the stepwells were met with disapproval by the British, who considered them to be unsanitary and discouraged their use. Many of these stepwells have been sealed off, perhaps as a response to health concerns raised by the guinea worm epidemic campaigns of the 1980s and 1990s (Livingston 2002). As a result, these structures entered a state of steady decline during the 19th and 20th centuries. Of the 17 stepwells we surveyed in 2016, only three had water. Moreover, industrial expansion towards the east from 1850s-1950s and rapid urban sprawl towards the west from the 1950s onwards have led to dramatic alterations in the surface hydrology, minimized percolation and overexploitation of groundwater reserves via bore wells (Shah 2005).

\section{Re-interpretation of water heritage-strategies for Jethabhai's stepwell}

Towards south-east Ahmedabad, in the historic suburb of Isanpur, we came across Jethabhai-ni-vaav (Jethabhai's stepwell) - a large and rather ornate mid-19th century stepwell named after its patron Jethabhai Jivanlal Nagjibhai. The stepwell was originally part of an orchard (Jain-Neubauer 1981). Today, this stepwell is surrounded by a water-stressed neighborhood, and Isanpur is now an administrative block within the Ahmedabad Municipal Corporation. Though the stepwell has been declared a monument of national importance by the ASI, it lies choked from disuse over the years. Based on local accounts, there was an unexplained surge of water in the well in 2014 after years of running dry. The whole neighborhood flocked to the well to witness the spectacle. However, as recently as 2017, the ASI undertook restoration of the site (Shastri 2018) and the well shaft was once again choked with rubble from the building work. It is hard to miss the irony of a protected water monument having its main source of water blocked while the vast expanse of manicured lawns around the stepwell are maintained by the ASI using water from a borewell. As a matter of fact, the ASI has a Horticulture Branch, which actively maintains gardens around grand mausoleum sites in Northern India where "the gardens are primarily intended to provide a setting for the monuments and to make the surroundings attractive" (Archaeological Survey of India 2020). 
The current practices that deal with the protection and restoration of historic water structures need to move beyond decontextualized musealization of monuments. Water structures such as stepwells have an especially enduring legacy because they invoke a collective reverence for shared natural resources in past societies. They represent a kind of subtractive architecture that revealed itself very discreetly at the ground level but hosted a complex ecosystem of seasonal fluxes and social functions within its depths. From the perspective of conservation practices, sites like these have the potential to act as testing grounds to actually demonstrate the operational aspects of historic water infrastructure and thus re-interpret the meaning of water heritage.

Having visited this site over several years, there are a few recommendations we would like to offer. First, the site's primary role as a communal water source should be acknowledged by again making it the main source of water for the site. This would require a concerted effort to unclog the well shaft and to allow the groundwater to recharge and reemerge. This could be achieved by reducing dependence on the industrial borewell and grading the surrounding ground for maximum infiltration of rainwater during the critical period of the annual monsoon. Secondly, instead of the static carpet of water intensive lawns, the landscape around the stepwell could emulate the dynamic seasonal changes which are also demonstrated by the shifting water levels within the stepwell. Thirdly, the site could be envisioned as a live demonstration of a cyclical water ecology where the processes of water percolation, recharge, extraction and use as a self-sustaining system are visible. Such a re-interpretation of water heritage, in what is essentially a public space, would help to shift the pervasive public attitudes towards groundwater from being an infinite source at the disposal of human consumption to that of respect for its natural rhythms.

\section{References}

Archaeological Survey of India (2020) Horticultural branch. https://asi.nic.in/horticulture-branch/. Accessed 28 June 2020

D'Souza R (2006) Water in British India: the making of a 'colonial hydrology'. History Compass 4(4):621628. https://onlinelibrary.wiley.com/doi/abs/10.1111/j.1478-0542.2006.00336.x. Accessed 28 June 2020

Jain-Neubauer J (1981) The Stepwells of Gujarat: In Art-historical Perspective. Abhinav Publications, New Delhi

Livingston M (2002) Steps to water: the ancient stepwells of India. Princeton Architectural Press, New York Mehta, R. N., and Ramesh Jamindar (2008) "Urban Context." In Ahmadabad, edited by George Michell and Snehal Shah, 16-29. Marg Foundation, Bombay.

Mehta Bhatt P (2014) Her space, her story: exploring the stepwells of Gujarat. Zubaan, New Delhi

Narain S, Agarwal, A (1997) Dying wisdom: rise, fall and potential of India's traditional water harvesting systems. Centre for Science and Environment, New Delhi

Shah P (2005) Strategy to revitalize urban water bodies: case of semi-arid Gujarat, India. Master's thesis. The International Institute for Geo-Information Science and Earth Observation, Enschede

Shastri P (2018) ASI gives Jethabhai ni Vav a facelift. The Times of India. https://timesofindia.indiatimes .com/city/ahmedabad/asi-gives-jethabhai-ni-vav-a-facelift/articleshow/62585640.cms. Accessed 28 June 2020

Sheth P, Jain T, Tayyibji R (2018) Stepwells of Ahmedabad-exhibition at Yale architecture. Architexturez South Asia, August 8. https://architexturez.net/doc/az-cf-188335. Accessed 28 June 2020

Publisher's Note Springer Nature remains neutral with regard to jurisdictional claims in published maps and institutional affiliations. 